\title{
Prediksi Harga Sembako di DKI Jakarta Menggunakan Artificial Neural Network
}

\author{
KHOLIDAH SYADIAH ${ }^{1}$, YULISON HERRY CHRISNANTO ${ }^{2}$, GUNAWAN ABDILLAH NAMA ${ }^{3}$ \\ 1,2,3 Jurusan Teknik Informatika, Fakultas SI \\ Universitas Jenderal Achmad Yani \\ Jl. Terusan Sudirman, Cimahi \\ Email : kholidahsyadiahif@gmail.com¹,y.chrisnanto@gmail.com², abi_zakiyy@gmail.com³
}

\begin{abstract}
ABSTRAK
Indonesia merupakan salah satu negara berkembang yang pertumbuhan ekonominya stabil. Hal ini dapat dilihat dari data statistik yang dikeluarkan oleh Badan Pusat statistik nasional. Pertumbuhan ekonomi yang stabil tidak diimbangi dengan stabilnya harga komoditas sembako di Indonesia khususnya di provinsi DKI Jakarta. Kondisi tersebut terlihat dari harga komoditas sembako (Sembilan Bahan Pokok) yang bergerak fluktuatif. Kenaikan harga BBM, cuaca serta adanya hari-hari besar menjadi faktor umum yang mempengaruhi harga komoditas sembako. Akibatnya harga komoditas sembako tidak dapat ditentukan karena kondisi-kondisi yang mempengaruhinya. Oleh karena itu, diperlukan model komputasi yang dapat memprediksi harga komoditas sembako di DKI Jakarta menggunakan metode yang memiliki akurasi yang baik. Pada penelitian sebelumnya pernah dilakukan penelitian prediksi harga dengan komoditas yang berbeda menggunakan metode Artificial Neural Network dengan akurasi 78\% hingga $86 \%$. Penelitian ini menghasilkan Sistem Prediksi Harga Sembako di DKI Jakarta menggunakan metode Artificial Neural Network. Dengan hasil terbaik didapatkan dengan parameter learning rate 0.01 dan toleransi error 0.01 dengan maksimum iterasi 500 yaitu akurasi sebesar $82 \%$ komoditas beras, $80 \%$ untuk komoditas Cabe dan $78 \%$ untuk komoditas bawang merah yang dihasilkan dari pengujian terhdap data uji.
\end{abstract}

Kata kunci: komoditas sembako; artificial neural network (ann); backpropagation.

\section{PENDAHULUAN}

Indonesia merupakan salah satu negara berkembang yang pertumbuhan ekonominya stabil. $\mathrm{Hal}$ ini dapat dilihat dari data statistik yang dikeluarkan oleh Badan Pusat statistik nasional yang menunjukkan angka pertumbuhan ekonomi Indonesia yang berada pada kisaran angka 5 persen dalam kurun waktu 3 tahun terakhir yaitu tahun 2016 sebesar 4,88 persen,tahun 2016 sebesar 5,02 persen dan tahun 2018 sebesar 5,07 persen. Kondisi ini juga didukung dengan banyaknya provinsi di Indonesia yang pertumbuhan ekonominya stabil dan cenderung melampaui angka nasional salah satunya Provinsi DKI Jakarta. Pada tahun 2016 sebesar 5,88 persen, tahun 2017 sebesar 5,85 persen dan tahun 2018 sebesar 6,22 persen.

Pertumbuhan ekonomi yang stabil tidak diimbangi dengan stabilnya harga komoditas sembako di Indonesia termasuk di provinsi DKI Jakarta. Kondisi tersebut terlihat dari data komoitas pangan di bank data DKI Jakarta yang menunjukkan harga komoditas sembako (Sembilan Bahan Pokok) bergerak secara fluktuatif. Sembilan bahan pokok yaitu beras, telur ayam, daging ayam, daging sapi, bawang merah, cabai, minyak goreing, gula dan jagung. Diantara sembilan bahan pokok yang ada harga komoditas beras, cabai dan bawang merah memiliki harga yang paling fluktiatif. Untuk komoditas hasil pertanian, bahan bakar fosil juga mempengaruhi fluktuasi harga. Stok juga dapat mempengaruhi harga, stok yang rendah akan menyebabkan harga meningkat di pasar [1]. 
Pada penelitian sebelumnya telah dilakukan prediksi dengan subjek yang berbeda yaitu prediksi harga ayam dengan menggunakan metode Backpropagation [2]. Prediksi harga komoditas pertanian menggunakan hybrid algoritma jaringan syaraf tiruan arsitektur Elman dengan Algortima Genetika menghasilkan prediksi harga dengan rata-rata MAPE training sebesar 25,786 dan rata-rata MAPE testing 44,6772 dengan parameter algoritma genetika probabilitas cross-over $(\mathrm{Pc})$ 0,6 dan 0,8, probabilitas mutasi (Pm) 0.1, ukuran populasi 50, dan generasi maksimum 500 [3]. Prediksi harga komsumen berdasarkan kelompok kesehatan menggunakan algoritma backpropagation dengan hasil terbaik yang didapat yaitu sebesar $92 \%$ dengan 12 lapisan input, 70 lapisan tersembunyi dan 1 lapisan keluaran [4]. Pada penelitian ini akan dibangun sebuah model komputasi yang dapat memprediksi harga komoditas sembako di DKI Jakarta menggunakan metode Artificial Neural Network (ANN). Prediksi dilakukan dengan analisa data historis harian harga sembako dalam kurun waktu 3 tahun yaitu 2016-2018 serta faktor-faktor yang mempengaruhi harga komoditas sembako yang digunakan untuk data latih. Hasil keluaran dari penelitian ini berupa prediksi harga komoditas sembako.

\section{METODE}

Backpropagation merupakan algoritma pelatihan terbimbing yang mempunyai banyak lapisan. Pada bckpropagation terdapat tahapan perbaikan bobot yang dilakukan dengan mengkoreksi kesalahan setiap layer dengan cara mundur atau backward.

Pada penelitian ini dilakukan prediksi harga komoditas sembako pada hari ke 31 dengan menganalisa data historis harga sembako dan faktor yang mempengaruhi 30 hari sebelumnya. Sistem prediksi harga sembako ini mengahasilkan satu nilai yang merupakan hasil analisis data 30 hari sebelumnya. Nilai keluaran yang dihasilkan didenormalisasi sehingga menghasilkan prediksi berupa harga komoditas sembako. Arsitektur Artificial Neural Network (ANN) yang digunakan terdiri dari 150 neuron input layer, 2 hidden layer dengan jumlah neuron masingmasing 11 neuron dan 20 neuron, dan 1 output layer. Arsitektur Artificial Neural Network (ANN) sistem prediksi harga sembako dapat dilihat pada Gambar 1.

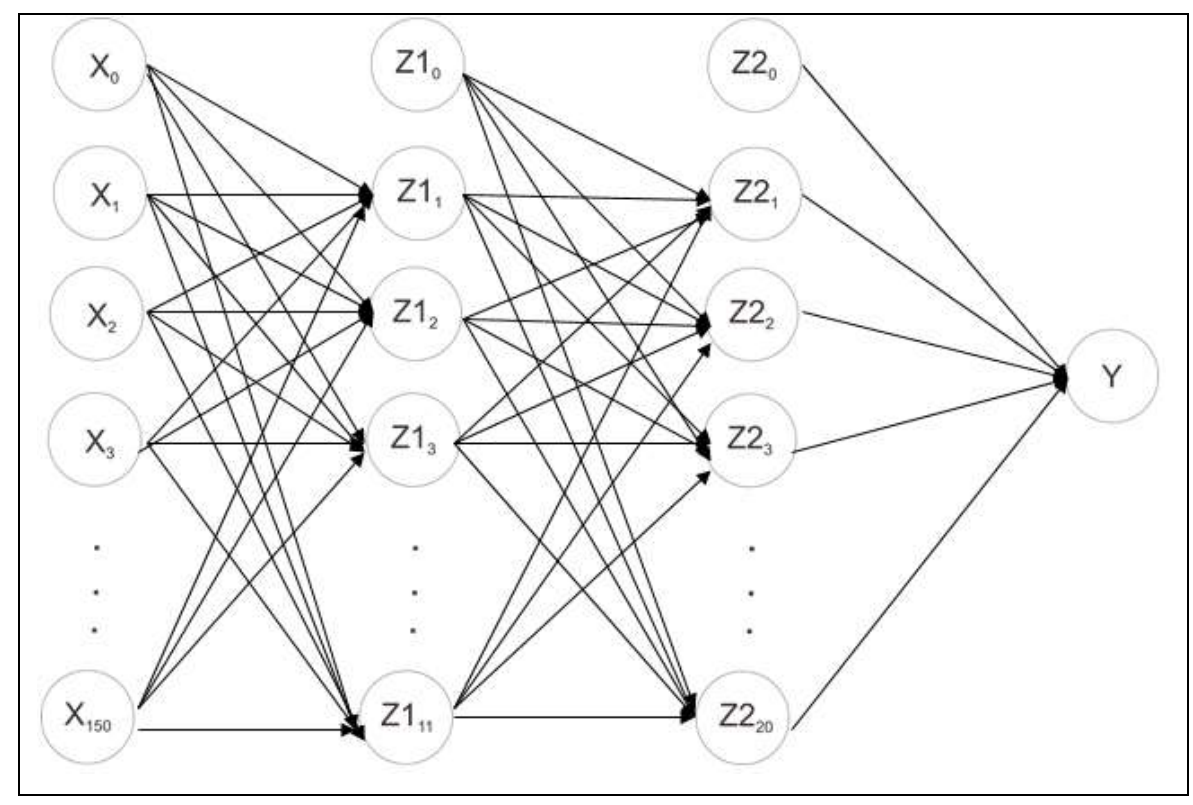

Gambar 1. Arsitektur Sistem Prediksi Harga Sembako

\section{A. Perolahan Data}

Pada penelitian sebelumnya telah dilakukan prediksi harga prediksi harga bahan pokok nasional jangka pendek menggunakan ARIMA dengan hasil rata-rata error sebesar 2.22\%[5]. Pada penelitian ini dilakukan prediksi harga sembako menggunakan Artificial Neural Network (ANN) menggunakan data harga komoditas sembako dan faktor yang mempengaruhinya. Data yang

Paper ini berasal dari Konferensi Nasional SNIA 2019 pada 26 September JUMANJI - 35

2019 bertempat di Hotel Grand Aquila Bandung 
digunakan adalah data harga komoditas sembako yang diperoleh dari bank data DKI Jakarta[6], data cuaca diperoleh dari data Badan Meteorologi Klimatalogi dan Geofisika (BMKG)[7]. Data cuaca yang diambil merupakan data cuaca dari daerah pemasok komoditas untuk DKI Jakarta. Data cuaca daerah yang diambil untuk masing-masing komoditas beras, cabai merah, dan bawang merah secara berurutan yaitu daerah Jember, Brebes, dan Banyuwangi. Data harga BBM dari data Badan Pelaksana Kegiatan Usaha Hulu Minyak dan Gas (BPMIGAS)[8] dan pasokan komoditas didapat dari data Kementrian Perdagangan[9]. Data yang digunakan yiatu data harian dari tahun 2016 - 2018 dimana data yang didapat dibagi menjadi data latih dan data uji. Sehingga data diperoleh sebanyak $1096 \times 4$ faktor yang mempengaruhi $=4.384$ data. Data yang digunakan sebagai data uji adalah 1065 hari dan 31 hari terakhir sebagai data uji. Setelah itu dilakukan cleaning data terlebih dahulu untuk menghilangkan data yang tidak digunakan. Selanjutnya dilakukan segmentasi data latih sebanyak 1065 secara overlap dimana antar dataset memiliki selisih 1 hari misalkan dataset ke- 1 yaitu data hari ke $1-30$, dataset ke- 2 yaitu data hari ke 2 - 31 dan seterusnya hingga dataset ke- 1035 yaitu data hari ke 1035 - 1065, sehingga terbentuk dataset hasil segmentasi sebanyak 1035. Pada satu set data terdiri dari 5 variabel, sehingga banyaknya masukkan pada ANN adalah 5 variabel x 30 hari $=150$ data masukkan. Kemudian data keluaran berupa harga komoditas sembako yang akan dikelaskan kedalam 3 kelas yaitu harga tinggi, harga stabil dan harga rendah. Kelas ini diambil berdasarkan nilai tengah dari harga tiap komoditas kenaikan dan turunya harga sebesar $10 \%$ dari nilai harga rata-rata tiap komoditas.

\section{B. Pra proses}

Pada pra proses terdapat 3 tahap yaitu cleaning data, segmentasi dan normalisasi. Cleaning data dilakukan untuk menghilangkan data yang tidak digunakan. Lalu masuk ketahap segmentasi dimana data diambil secara overlap dengan selisih antar data satu hari. Proses segmentasi diilustrasikan seperti pada Gambar 2. Setelah itu dilakukan normalisasi.

Hari ke -

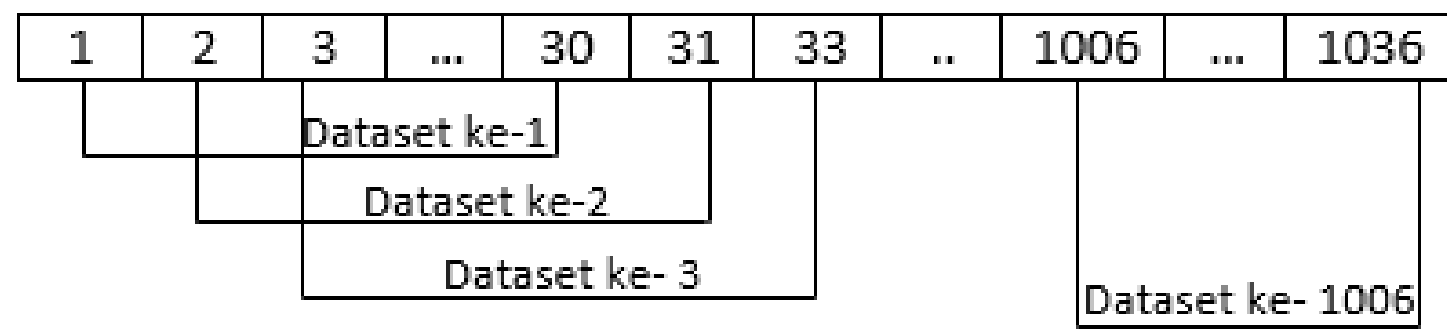

Gambar 2. Segmentasi Data Secara Overlap

Normalisasi adalah proses mengubah data yang memiliki nilai yang sangat besar atau sangat kecil dan memiliki satuan yang berbeda. Normalisasi dilakukan menggunakan persamaan 1.

$$
Z=\frac{x-\min ()}{\max ()-\min ()}
$$

Keterangan:

Z : hasil normalisasi

$\mathrm{x}$ : nilai yang akan dinormalisasi

$\min =$ nilai minimum data dalam kolom

$\max =$ nilai maximum data dalam kolom . 


\section{Proses Prediksi Harga Sembako}

Proses prediksi harga sembako dimulai dengan tahap pelatihan, dimana data yang telah tersegmentasi dan ternormalisasi masuk ke proses pelatihan menggunakan algoritma Backpropagation. Dalam algoritma backpropagation terdapat 3 tahapan yaitu feedforward untuk pelatihan data input, backpropagation untuk koreksi kesalahan disetiap layerdan terkahir perbaikan bobot. hasil pelatihan berupa bobot yang akan disimpan ke dalam database.

1)Tahapan Feedforward

Adapun tahapan feedforward yaitu:

a)Tiap neuron masukan menerima sinyal dan meneruskannya ke neuron-neuron dalam lapisan tersembunyi.

b)Hitung semua keluaran di neuron-neuron tersembunyi menggunakan persamaan 2.

$$
z_{n e t j}=v_{j 0}+\sum_{i=1}^{n} x_{i} v_{j i}
$$

Keterangan:

$V j_{0} \quad=$ Bias pada lapisan masukan

$n \quad=$ Jumlah neuron masukan

$x_{i} \quad=$ Data pada neuron ke-i

$v j_{i} \quad=$ Bobot dari neuron masukan ke-i menuju neuron tersembunyi ke-j

c) Kemudian menerapkan fungsi aktivasi untuk menghitung sinyal hidden layer menggunakan persamaan 3.

$$
z_{j}=f\left(z_{n e t j}\right)
$$

2)Tahapan Backward

a)menghitung faktor $\delta$ (error) unit keluaran berdasarkan error disetiap unit keluaran $y k$ menggunakan persamaan 4.

$$
\delta_{k}=\left(t_{k}-y_{k}\right) f^{\prime}\left(y_{n e t_{k}}\right)\left(t_{k}-y_{k}\right)\left(1+y_{\text {netk }}\right)\left(1-y_{\text {net }}\right)
$$

Keterangan:

$t k \quad=$ Pola target ke-k

$y k=$ Neuron keluaran ke-k

$f^{\prime}(y n e t k)=$ Turunan dari keluaran pada neuron keluaran ke-k

b)Setelah itu, hitung delta bobot menggunakan persamaan 5.

$$
\Delta w_{k j}=\propto \delta_{k} z_{j}
$$

Keterangan:

$\alpha=$ Laju pembelajaran

$\delta_{k}=$ Error pada neuron keluaran ke-k

$z_{j}=$ Keluaran yang telah diaktivasi pada lapisan tersembunyi ke-j.

3)Perbaikan Bobot 
a)Lakukan perbaikan bobot dan bias menuju lapisan keluaran dengan menambahkan nilai bobot lama dengan delta bobotnya, dan nilai bias lama dan delta biasnya menggunakan persamaan 6 dan 7.

$$
\begin{aligned}
& w_{k i}(\text { baru })=w_{k j}(\text { lama })+\Delta w_{k j} \\
& w_{0 k}(\text { baru })=w_{0 k}(\text { lama })+\Delta w_{0 k}
\end{aligned}
$$

Keterangan:

$\mathrm{w} \_\mathrm{kj}($ baru $) \quad=$ Bobot baru hasil perbaikan bobot dari neuron hidden layer ke-j menuju neuron keluaran ke-k

$\mathrm{w} \_\mathrm{kj}$ (lama) = Bobot awal dari neuron hidden layer ke-j menuju neuron keluaran ke-k $\Delta w k j=$ Koreksi bobot dari neuron hidden layer ke-j menuju neuron keluaran ke-k $w 0 \mathrm{k}$ (baru) = Bobot bias baru hasil perbaikan bobot dari neuron tersembunyi ke-j menuju neuron keluaran ke-k

$w 0 \mathrm{k}$ (lama) = Bobot bias awal dari neuron hidden layer ke-j menuju neuron keluaran ke-k $\Delta w k j=$ Koreksi bobot dari neuron hidden layer ke-j menuju neuron keluaran ke-k.

b)Lakukan juga perbaikan bobot dan bias menuju lapisan tersembunyi menggunakan persamaan 8 dan 9.

$$
\begin{aligned}
& V_{i j}(\text { baru })=V_{i j}(\text { lama })+\Delta V_{i j} \\
& V_{0 j}(\text { baru })=V_{0 j}(\text { lama })+\Delta V_{0 j}
\end{aligned}
$$

Keterangan:

$\mathrm{Vij}$ (baru) $=$ Bobot baru hasil perbaikan bobot dari neuron input ke-i menuju neuron hidden layer ke- $\mathrm{j}$.

$\mathrm{Vij}($ lama $)=$ Bobot awal dari neuron input $\mathrm{i}$ ke- $\mathrm{i}$ menuju neuron hidden layer ke- $\mathrm{j}$.

$\Delta \mathrm{Vij}=$ Koreksi bobot dari neuron input ke- i menuju neuron hidden layer ke-k

v0j (baru) = Bobot baru hasil perbaikan bobot dari neuron input ke-i menuju neuron hidden layer ke- $\mathrm{j}$.

V0j (lama) = Bobot awal dari neuron input ke- $\mathrm{i}$ menuju neuron hidden layer ke- $\mathrm{j}$.

$\Delta \mathrm{V} 0 j=$ Koreksi bobot dari neuron masukkan ke- i menuju neuron tersembunyi ke-k.

Pada penelitian ini fungsi aktivasi yang digunakan dalam Artificial Neural Network yaitu tangent hyperbolic atau tanh seperti yang diperlihatkan pada persamaan 10.

$$
r(c)=\tanh (c)=\frac{e^{c}-e^{-c}}{e^{c}+e^{-c}}
$$

Keterangan:

e = bilangan eksponensial

$\mathrm{c}=$ bilangan konstanta/nilai masukkan. 
Bobot yang dihasilkan pada proses pelatihan digunakan untuk proses prediksi menggunakan feedforward pada arsitektur Multi Layer Perceptron (MLP). Hasil prediksi berupa nilai yang akan didenormalisasi menggunakan persamaan 11. Kemudian akan dikelaskan berdasarkan interval harga yaitu harga tinggi, harga stabil dan harga rendah.

$$
x=Z *(\max -\min )+\min
$$

Dimana $\mathrm{x}$ adalah nilai aktual/terdenormalisasi, $\mathrm{Z}$ nilai ternormalisasi, max nilai maksimum data dan min adalah nilai minimum data.

\section{HASIL DAN DISKUSI}

Pada penelitian ini dilakukan tiga pengujian yaitu pengujian optilmalisasi parameter, pengujian pengaruh jumlah hidden layer dan pengujian terhdap data data uji.

\section{A. Pengujian Optimalisasi parameter}

pengujian optimalisasi parameter dilakukan dengan memasukkan nilai parameter oleh pengguna. Adapn parameter yang dimaksud yaitu maksimum epoch, minimum error dan learning rate. Maksimum epoch berfungsi untuk mengendalikan jumlah iterasi saat pelatihan. Learning rate digunakan untuk mengendalikan proses pembelajaran, semakin kecil nilai learning rate maka akan semakin detail pembelajaran yang dilakukan saat proses pelatihan menggunakan Backpropagation. Adapun hasil pengujian optimalisais parameter dapat dilihat pada Tabel 1.

TABEL 1. Pengujian Optimalisasi Parameter

\begin{tabular}{|c|c|c|c|c|c|c|c|}
\hline \multirow[t]{2}{*}{ Komoditas } & \multirow[t]{2}{*}{ Epoch } & \multirow[t]{2}{*}{ Alpha } & \multirow{2}{*}{$\begin{array}{l}\text { Minimum } \\
\text { Error }\end{array}$} & \multirow{2}{*}{ MSE } & \multirow{2}{*}{ Waktu } & \multicolumn{2}{|c|}{ Akumsi } \\
\hline & & & & & & DL & DU \\
\hline \multirow{4}{*}{ Beras } & \multirow{4}{*}{500} & \multirow[b]{2}{*}{0.1} & 0.1 & 0.0888835 & $00: 00: 02$ & 82 & 79 \\
\hline & & & 0.01 & 0.0114322 & $00: 07 ; 35$ & 91 & 82 \\
\hline & & \multirow[b]{2}{*}{0.01} & 0.1 & 0.0996751 & $00: 00: 02$ & 60 & 54 \\
\hline & & & 0.01 & 0.0111342 & $00: 08: 61$ & 84 & 79 \\
\hline \multirow{4}{*}{ Cabai } & \multirow{4}{*}{500} & \multirow[b]{2}{*}{0.1} & 0.1 & 0.0018835 & $00: 00: 03$ & 80 & 78 \\
\hline & & & 0.01 & 0.0085260 & $00: 00: 05$ & 90 & 80 \\
\hline & & \multirow[b]{2}{*}{0.01} & 0.1 & 0.0796789 & $00: 00: 05$ & 70 & 63 \\
\hline & & & 0.01 & 0.0145473 & $00: 05: 21$ & 84 & 79 \\
\hline \multirow{4}{*}{ Bawang } & \multirow{4}{*}{500} & \multirow[b]{2}{*}{0.1} & 0.1 & 0.0888835 & $00: 00: 02$ & 85 & 76 \\
\hline & & & 0.01 & 0.0114322 & $00: 07: 35$ & 88 & 78 \\
\hline & & \multirow[b]{2}{*}{0.01} & 0.1 & 0.0996751 & $00: 00: 02$ & 76 & 68 \\
\hline & & & 0.01 & 0.0111342 & $00: 08: 61$ & 79 & 71 \\
\hline
\end{tabular}

Berdasarkan hasil pengujian optimalisasi parameter hasil akurasi dapat dilihat pada kolom DL yang artinya Data Latih dan DU yang artinya Data Uji. Terlihat pada tabel 2 nilai alpha yang semakin kecil berpengaruh terhadap lamanya waktu pelatihan dimana waktu yang dibutuhkan akan semakin lama. Berbeda halnya dengan nilai minimum error, semakin kecil minimum error yang ditentukan maka akan semakin besar akurasi yang didapatkan sehingga perlu dicari kombinasi antara parameter yang tepat. Pada pengujian ini didapatkan parameter terbaik yaitu epoch 500 dengan minimum error 0.01 dan learning rate 0.1 menghasilkan akurasi untuk komoditas cabai $91 \%$ data latih dan $82 \%$ data uji, komoditas cabai merah $90 \%$ data latih dan $80 \%$ data uji sedangkan untuk komoditas bawang merah yaitu $88 \%$ data latih dan $78 \%$ data uji. Akurasi didapatkan dari hasil kesesuaian prediksi dengan data aktual. Dimana jumlah hasil yang sesuai dibagi jumlah keseluruhan data. 


\section{B. Pengaruh Jumlah Hidden Layer}

Pengujian terhadap pengaruh jumlah hidden layer terhadap akurasi sistem dengan parameter yang sama yaitu epoch 500 learning rate 0.1 dan toleransi error 0.01 dapat dilihat pada Tabel 2.

TABEL 2. Hasil Uji Pengaruh Jumlah Hidden Layer

\begin{tabular}{|c|c|c|c|c|c|}
\hline Komoditas & \multirow{2}{*}{$\begin{array}{c}\text { Jumlah } \\
\text { hidden } \\
\text { layer }\end{array}$} & MSE & \multirow{2}{*}{ Waktu } & \multicolumn{2}{|c|}{ Akurasi } \\
\cline { 5 - 6 } & 1 & 0.0122437 & $00: 04: 55$ & 85 & 78 \\
\hline \multirow{3}{*}{ Beras } & 2 & 0.0114322 & $00: 07: 35$ & 91 & 82 \\
\hline \multirow{3}{*}{ Cabai } & 1 & 0.0188563 & $00: 00: 03$ & 83 & 74 \\
\cline { 2 - 6 } & 2 & 0.0144323 & $00: 00: 05$ & 90 & 80 \\
\hline \multirow{3}{*}{ Bawang } & 1 & 0.0145473 & $00: 04: 32$ & 84 & 69 \\
\cline { 2 - 6 } & 2 & 0.0114322 & $00: 07: 35$ & 88 & 78 \\
\hline
\end{tabular}

Hasil pengujian terhadap jumlah hidden layer menunjukkan akurasi pada kolom DL(Data Latih) dan DU (Data Uji) untuk setiap komoditas dengan arsitektur 2 hidden layer memiliki akurasi yang lebih tinggi.

\section{Hasil Prediksi Harga Sembako Terhadap Nilai Aktual}

Hasil prediksi harga sembako terhadap Nilai aktual diperlihatkan secara visualisasi yang dapat dilihat pada grafik hasil prediksi saat pelatihan salah satu komoditas yaitu beras yang dapat dilihat pada Gambar 2.

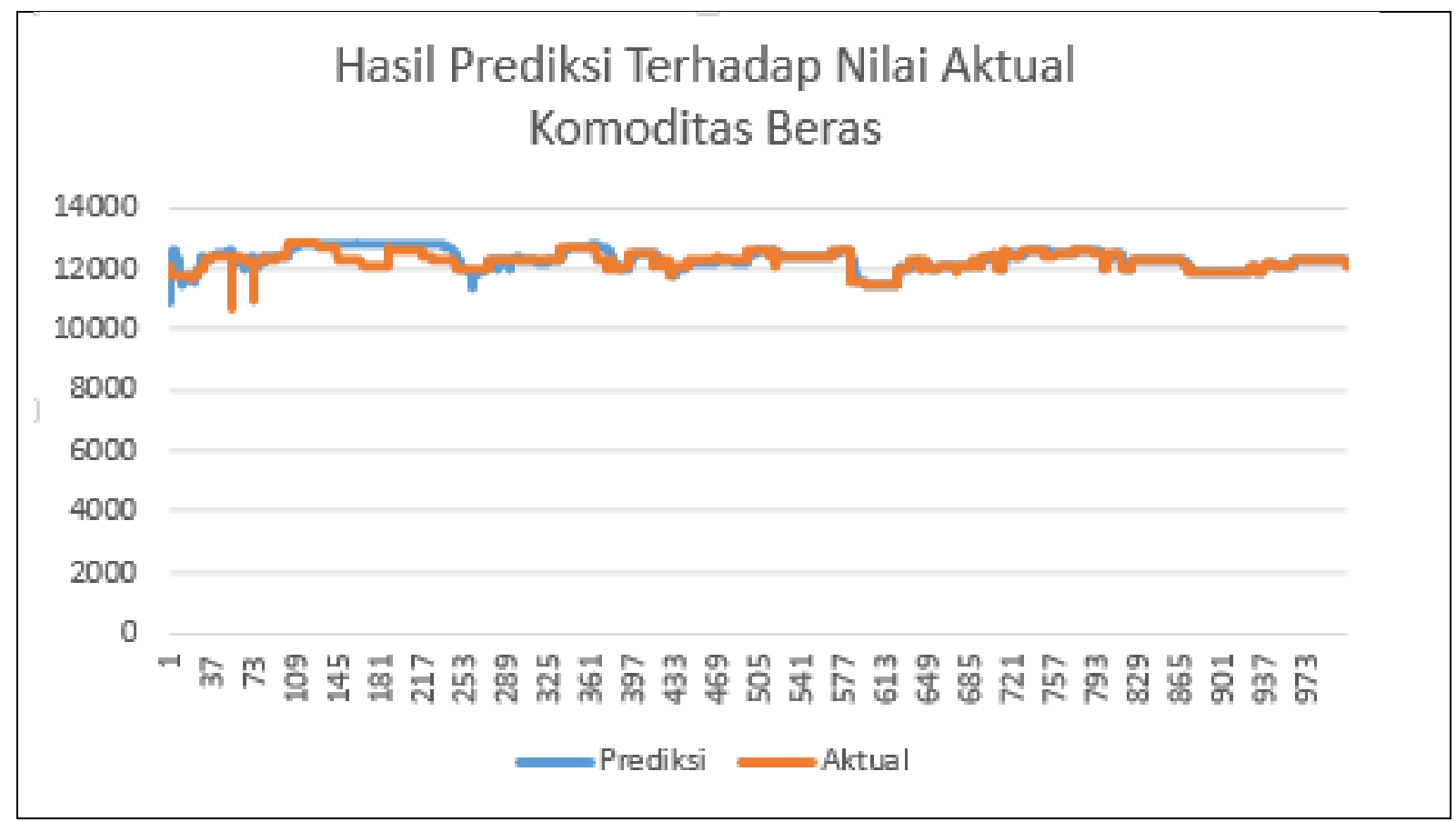

Gambar 3. Grafik hasil prediksi dengan nilai aktual 
Pada Gambar 2 terlihat garis hasil prediksi pada proses pelatihan memperlihatkan garis antara hasil prediksi dengan nilai aktual semakin lama semakin berhimpit yang artinya hasil prediksi mendekati nilai aktualnya.

\section{KESIMPULAN}

Berdasarkan tujuan penelitian ini telah mengahasilkan sebuah sistem prediksi harga sembako mengunakan Artificial Neural Network (ANN). Sistem prediksi harga sembako dirancang untuk memprediksi harga komoditas sembako yaitu beras, cabai, dan bawang merah dengan menganalisis pola data historis harian harga komoditas sembako dan faktor yang mempengaruhinya 30 hari sebelumnya. Sistem prediksi harga sembako telah melalui dua tahap pengujian yaitu pengujian kualitas dan akurasi. Pengujian sistem merupakan pengujian yang dilakukan untuk menguji fungsionalitas sistem. Sedangkan untuk pengujian akurasi dilakukan untuk melihat pengaruh parameter yang digunakan dalam sistem, dan pengujian prediksi untuk data latih serta data baru.

Pelatihan menggunakan algoritma Backpropagation menghasilkan parameter terbaik yaitu epoch 500, learning rate 0.1 dan toleransi error 0.01 dengan akurasi untuk komoditas beras $91 \%$ untuk data latih dan $82 \%$ untuk data uji dan komoditas bawang $88 \%$ untuk data latih dan $78 \%$ data uji sedangkan untuk komoditas cabai didapat akurasi sebesar $90 \%$ data latih dan $80 \%$ data uji. Dalam beberapa pengujian dengan parameter tertentu, kondisi berhenti tidak selalu mencapai nilai maksimum epoch ini terjadi karena nilai errorsudah lebih kecil atau sama dengan minimum error sehingga pada kondisi ini maksimum epoch tidak berpengaruh. Pada pengujian pengaruh jumlah hidden layer didapat arsitektur dengan jumlah hidden layer lebih banyak memiliki akurasi yang lebih baik.

Pada penelitian selanjutnya dapat menambah jumlah komoditas yang diprediksi yaitu gula, minyak goreng, telur, daging ayam dan daging sapi. Faktor yang mempengaruhi harga komoditas bisa ditambah dengan data demand atau permintaan terhadap komoditas yang diprediksi, dan menambah data 2 tahun sebelumnya untuk memperoleh proses pembelajaran yang lebih beragam.

\section{DAFTAR PUSTAKA}

[1] M. A. Reza, "Analisis Stabilisasi Harga Pangan Di Indonesia" vol. III, no. 1, 2015.

[2] S. Nanik, "Penerapan Model Neural Network Backpropagation" in Prosiding SNATIF, 2014.

[3] Dewa Made Rai Widyadarma, "Prediksi Harga Komoditas Pertanian Menggunakan Hybrid," e-Proceeding of Engineering, vol. III, no. 1, p. 1263, 2016.

[4] Wiguna Arif. Anjar Wanto, "Analisis Prediksi Indeks Harga Konsumen Berdasarkan Kelompok Kesehatan Dengan Menggunakan Metode Backpropagation," Publikasi Jurnal \& Penelitian Teknik Informatika, vol. II, no. 1, 2017.

[5] R. M. Arif, "Prediksi Harga Bahan Pokok Nasional Jangka Pendek Menggunakan ARIMA," Journal of Information Systems Engineering and Business Intelligence, vol. III, no. 2, pp. 108-112, 2017.

[6] Informatika. Statistik. Provinsi. DKI. Dinas Komunikasi, "Jakarta Open Data," [Online]. Available: https://data.jakarta.go.id. [Accessed 411 2018].

[7] BMKG, "Data Online Pusat Database BMKG," [Online]. Available: http://dataonline.bmkg.go.id. [Accessed 2002 2019].

[8] BPMIGAS, "Kementrian Energi dan Sumber Daya Mineral," [Online]. Available: https://migas.esdm.go.id. [Accessed 2901 2019].

[9] K. P. Indonesia, "Sistem Pemantauan Pasar Kebutuhan Pokok (S2PKP)," [Online]. Available: https://ews.kemndag.go.id. [Accessed 10 Februari 2019]. 